\title{
Evaluation of the Microbiological Quality of Different Moroccan Drinking Water in the Beni Mellal Region
}

\author{
Rachid Hnini*, Said Ihbour, Lhou Ouhida, Merzouki Mouhamed, Ahmed Ait Chaoui, Fatiha Chigr, \\ Mohamed Najimi
}

Laboratory of Biological Engineering, Pathology and Functional Biology Team, Sultan Moulay Slimane University, FST, Beni Mellal, Morocco

Email: *rachid.hnini@hotmail.com

How to cite this paper: Hnini, R., Ihbour, S., Ouhida, L., Mouhamed, M., Chaoui, A. A., Chigr, F., \& Najimi, M. (2019). Evaluation of the Microbiological Quality of Different Moroccan Drinking Water in the Beni Mellal Region. Journal of Geoscience and Environment Protection, 7, 105-115. https://doi.org/10.4236/gep.2019.75011

Received: April 4, 2019

Accepted: May 24, 2019

Published: May 27, 2019

Copyright ( $\odot 2019$ by author(s) and Scientific Research Publishing Inc. This work is licensed under the Creative Commons Attribution International License (CC BY 4.0).

http://creativecommons.org/licenses/by/4.0/

cC) (i) Open Access

\begin{abstract}
Drinking water is water that does not contain pathogens or chemicals at levels that may be harmful to health. Beni Mellal region, one of the major rich areas in ground and surface water in Morocco (the rivers like Oum Errabia, Darna, ...; Bin el-Ouidane and martyr Ahmed El Hansali dams and sources like Ain Asserdoune, ...) is located in the North-Centre of Morocco. The main objective of the present study was to evaluate the microbiological quality of different drinking waters originated from sources, faucets, fountains and wells in the Beni Mellal city and its agricultural surrounding areas. For this, hygienic quality indicator parameters of water quality were determined by assessing the analysis of Total Coliforms Count, Fecal Coliforms Count, streptococcus D and revivable germs while germs such as Anaerobic Sulphite-reducing Bacteria, $S$. aureus and Salmonella sp, were carried out according to national and international standards. The analysis of the microbiological results found for all the different samples waters investigated in this study revealed that the waters originated from fountains, faucets and sources were proper for main consumption at microbiological point of view while the wells waters were improper for consumption according to norms. Finally, it appears, from the results obtained, that the potential risk of infection of water consumers especially (groundwater) calls for prompt intervention in order to alleviate the potential health impact of water-borne diseases in the community. From this, a proper sanitary survey and implementation of water and sanitation projects in the community is recommended.
\end{abstract}

\section{Keywords}

Water Quality, Microbiological Analysis, Standards, Beni Mellal, Morocco 


\section{Introduction}

The importance of water, sanitation and hygiene for health and development is reflected by the findings of a series of international policy forums. Among the most recent is the adoption of the Sustainable Development Goals by countries in 2015 including a target and indicators for the safety of drinking water. In addition, the United Nations General Assembly declared in 2010 that safe and healthy drinking water and sanitation were a human right essential to the full enjoyment of life and the enjoyment of all Human Rights. These commitments are in line with longstanding support, including the adoption by the United $\mathrm{Na}$ tions General Assembly of the Millennium Development Goals in 2000 and the proclamation of the 2005-2015 International Decade for Action on the theme "Water is the source of life", OMS (2017). As the international authority responsible for public health and water quality, WHO leads global efforts in order to prevent the spread of water-borne diseases. To this objective, it promotes health regulations to governments and works with partners to encourage water providers, communities and households to adopt effective risk management practices. In past centuries, the use of water by humans has had no impact on the availability of water on the earth planet until the mid-nineteenth century Boyd (2007), but this water availability becomes a serious threat due to human demographics that experienced an exponential growth especially after the Second World War where the number of the world population tripled from 2.3 to 7.3 billion between 1940 and 2015, LeRoy (1995), and UN (2015). The water consumption per capita, has increased in the world, Boyd (2007). Nowadays, it takes 730,000 litres of water each year to feed and support an inhabitant of the planet, or 2000 lifters per day, ConsoGlobe (2019). Over the world, the largest per capita water users are Americans; for example, water volume consumed per capita for production of goods and services in the United States was only estimated at $2483 \mathrm{~m}^{3} /$ person/year (2.4 million litres per person or 6580 litres per day), and approximately 2332, 1682,1103 and $675 \mathrm{~m}^{3}$ are statistics of the volume of water consumed by each person per year in Italy, Switzerland, Poland and Ethiopia, respectively; while the world average is estimated in the order of $1243 \mathrm{~m}^{3} /$ person/year, ConsoGlobe (2019). In France, the volume of drinking water taken in 2012 was 5.4 billion $\mathrm{m}^{3}$. Today, the average consumption of a Frenchman was 148 litres per inhabitant per day Planete (2018); while in Morocco, the average consumption of a Moroccan man was about 70 litres per day. In some countries in Africa and in Asia which have a major lack of water quantity and quality, disequilibria is probably impossible to be controlled while some other parts of Asia, Latin America and Europe risk to face the same situation, Cosgrove \& Rijsberman (2014). Moreover, in rural communities in developing countries, the rationale for promoting safe drinking water in rural communities in developing countries is the persistently high levels of water associated morbidity and mortality, WHO (2003). Worldwide, drinking of unsafe water coupled with poor sanitation leads to mortality of at least 1.6 million children under the age of five every year; $84 \%$ of them are living in rural areas. If the current trend persists, nearly 1.7 billion rural 
dwellers will not have access to safe water and improved sanitation by 2015 , WHO \& UNICEF (2006). In this regards, provision of good quality household drinking water remains an important means of improving public health in rural communities especially in Africa; and is the rationale behind protecting drinking water sources and promoting healthy practices at and around such sources, Gwimbi (2011). The main objective of this study was to evaluate the microbiological quality of different drinking water originated from sources, faucets, fountains and wells in the Beni Mellal city in Morocco and its agricultural surrounding areas.

\section{Materials and Methods}

\subsection{Sampling Zones}

This work was performed in the Beni mellal city located in the north-central area of Morocco (Figure 1). Beni Mellal city is precisely situated in the administrative region of Beni Mellal-Khenifra in the center of Morocco. This city is limited to the west by the provinces of Kalaat Es-sraghna and $\mathrm{Al} \mathrm{Haouz,} \mathrm{to} \mathrm{the} \mathrm{north} \mathrm{by} \mathrm{the}$ provinces of Khouribga and Settat, to the east by the provinces of Errachidia and Khenifra and to the south by the province of Ouarzazate. From its location between two phosphate plateaus and the Middle Atlas, the region of Beni mellal-Khenifra with an average altitude of 400 to $700 \mathrm{~m}$ is characterized by a very continental climate, and the amount of rainfall varies between 300 and $750 \mathrm{~mm}$ depending on the year. Jellies are not uncommon in winter. The summer is very hot because of the hot south westerly winds-east "chergui" that increases mercury above $40^{\circ} \mathrm{C}$, these heat waves sometimes end with violent storms that cool the ground.

\subsection{Sampling Methods}

For what is related to the nature of sampling, we followed the protocol required
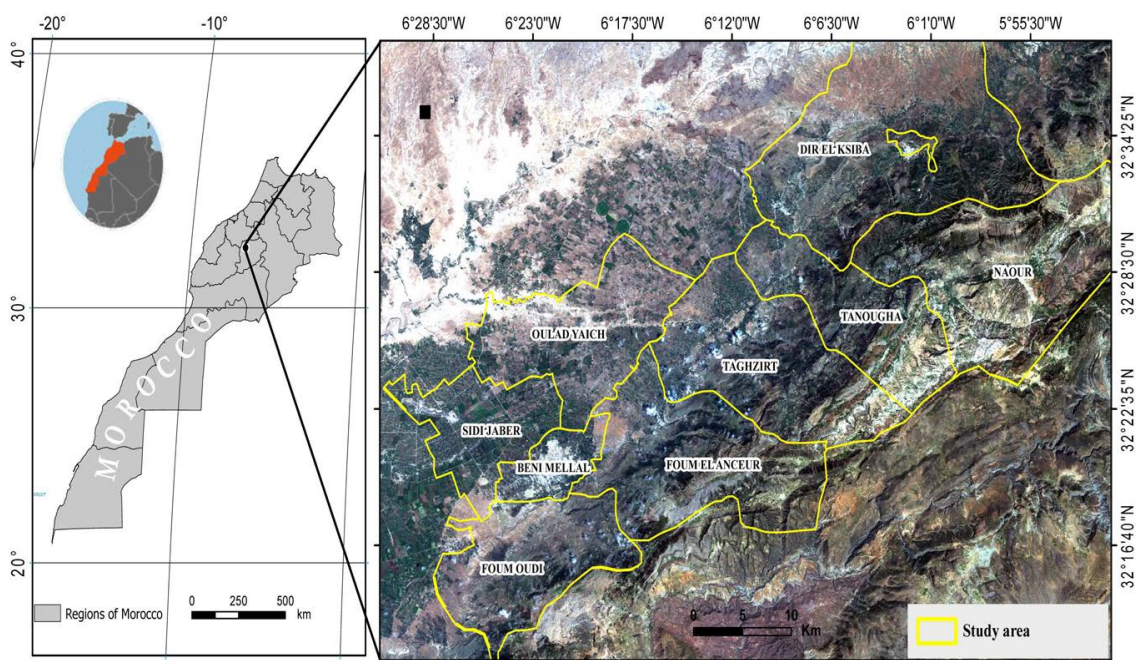

Figure 1. Beni Mellal city localization. 
by certain international standards ISO (2004), and ISO (2006), (case of the French standard NF ISO 5667-3 (June 2004) and NF ISO 19458 (November 2006)) which describe the way to perform a representative sampling for a microbiological analysis at a faucet, at a source and how to also take a sample from a well using a diver. Transport and conservation of a collected sample for analysis were carried out according to Henri (2002). Of note, weekly sampling in the morning between 10am and $1 \mathrm{pm}$ (time of rejection) was regularly carried out at the points chosen during the study period extended from April to June 2018, with one sampling per each selected point repeated each 15 days.

\subsection{Sampling Preparation}

According to aforementioned guidelines, a total of 120 samples water was collected from Beni Mellal city and in its agricultural surrounding areas at different points randomly selected (point $1=$ Treated water represented by faucets water in Beni Mellal city; point 2 = Untreated water representing by natural water of fountains in Beni Mellal city; point 3 = Untreated water representing by natural surface water of sources, Beni Mellal city provinces and point $\mathbf{4}=$ Groundwater representing by natural water of wells, agricultural surroundings of the Beni Mellal city) for microbiological analysis.

\subsection{Microbiological Analysis}

Water has been collected in sterile glass vials. Microbiological analyses have been started less than six hours after collection. If the transport exceeds six hours and the outside temperature is above $10^{\circ} \mathrm{C}$; transport has been done in a cool box at a temperature below $4^{\circ} \mathrm{C}$. Finally, the samples are placed in the cold of their arrival at the laboratory before the beginning of the analysis, AFNOR (1987). The researched germs, by using filtration methods, are: revivable germs ISO (1999), Coliforms AFNOR (1985), faecal Streptococci Rodier (1996), Spheres of Anaerobic Sulpho-Reducers ISO (1993), Salmonella AFNOR (1993), and S. aureus, Rodier (1996). The filtered bacteria on discs were inoculated on specific media and incubated at growth temperature corresponding for each bacterium. All microbiological analysis was performed at Biological Engineering Laboratory, Sultan Mouly Slimane University.

\section{Results}

The results of the obtained microbiological analyses performed in faucets, fountains and sources waters showed a total absence of faecal coliform count, total coliforms count and Streptococcus D count, S. aureus, Salmonella and Spheres of Anaerobic Sulpho-Reducers, respectively. However, the results of microbiological analyzes of wells waters were contaminated with an important load amount of faecal coliform, total coliforms, Streptococcus D, and $S$. aureus at threatening levels, which does not meet the standards of potability. Conversely pathogenic germs such as Salmonella and Spheres of Anaerobic Sulpho-Reducers 
were totally absent in wells waters. The essential of results of the microbiological analysis of waters in different studied points of Beni Mellal city and its agricultural surrounding areas are presented in Tables 1 to 4 .

\section{Discussion}

Drinking water is water that can be drunk without risk to health; standards have been established to define a specific drinking water, including the maximum levels that should not be exceeded for a number of harmful substances that may be

Table 1. Microbiological determinations at Fountains.

\begin{tabular}{|c|c|c|c|c|c|c|c|}
\hline \multirow[b]{2}{*}{ Charges } & \multicolumn{4}{|c|}{ Germs indicators of contamination } & \multicolumn{3}{|c|}{ Pathogens } \\
\hline & $\begin{array}{c}\text { R.G CFU } / 100 \mathrm{ml} \mathrm{à} \\
20^{\circ} \mathrm{C}\end{array}$ & $\mathrm{TC}$ CFU/100 ml & FC CFU $/ 100 \mathrm{ml}$ & Stre. D CFU/100 ml & $\begin{array}{c}\text { S. aureus } \\
\text { CFU/100 ml }\end{array}$ & $\begin{array}{l}\text { Salmonella } \\
\mathrm{CFU} / 100 \mathrm{ml}\end{array}$ & S.A.S CFU $/ 20 \mathrm{ml}$ \\
\hline Maximum & $3 \times 10^{6}$ & 49 & 00 & 00 & 00 & 00 & 00 \\
\hline Minimum & 52 & 00 & 00 & 00 & 00 & 00 & 00 \\
\hline Average & 689120.75 & 0.61 & 00.0 & 00.0 & 00.0 & 00.0 & 00.0 \\
\hline
\end{tabular}

R.G: Revivable Germs, TC: Total Coliforms, FC: Fecal Coliforms, Stre. D: Streptococcus D, S. aures: Staphylococcus aureus, S.A.S: Spheres of Anaerobic Sulpho-Reducers.

Table 2. Microbiological determinations at Sources.

\begin{tabular}{cccccccc}
\hline & \multicolumn{3}{c}{ Germs } & \multicolumn{2}{c}{ Germs indicators of contamination } & \multicolumn{3}{c}{ Pathogens } \\
\cline { 2 - 8 } Charges & $\begin{array}{c}\text { G.R CFU/100 ml at } \\
20^{\circ} \mathrm{C}\end{array}$ & TC CFU/100 ml & FC CFU/100 ml Stre. D CFU/100 ml & $\begin{array}{c}\text { S. aureus } \\
\text { CFU/100 ml }\end{array}$ & $\begin{array}{c}\text { Salmonella } \\
\text { CFU/100 ml }\end{array}$ & S.A.S CFU/20 ml \\
\hline Maximum & $400 \times 10^{3}$ & 00 & 00 & 00 & 00 & 00 & 00 \\
Minimum & 00 & 00 & 00 & 00 & 00 & 00 & 00 \\
Average & 35978.75 & 00.0 & 00.0 & 00.0 & 00.0 & 00.0 & 00.0 \\
\hline
\end{tabular}

Table 3. Microbiological determinations at Wells.

\begin{tabular}{cccccccc}
\hline \multicolumn{2}{c}{ Germs } & \multicolumn{3}{c}{ Germs indicators of contamination } & \multicolumn{3}{c}{ Pathogens } \\
\cline { 2 - 7 } Charges & $\begin{array}{c}\text { G.R CFU/100 ml at } \\
20^{\circ} \mathrm{C}\end{array}$ & TC CFU/100 ml & FC CFU/100 ml Stre. D CFU/100 ml & $\begin{array}{c}\text { S. aureus } \\
\text { CFU/100 ml }\end{array}$ & $\begin{array}{c}\text { Salmonella } \\
\text { CFU/100 ml }\end{array}$ & S.A.S CFU/20 ml \\
\hline Maximum & $280 \times 10^{5}$ & $300 \times 10^{6}$ & $245 \times 10^{4}$ & $40 \times 10^{2}$ & $603 \times 10^{4}$ & 00 & 00 \\
Minimum & $300 \times 10^{3}$ & $275 \times 10^{5}$ & $190 \times 10^{3}$ & 97 & $287 \times 10^{2}$ & 00 & 00 \\
Average & 35978.75 & $10850.25 \times 10^{4}$ & $78654 \times 10^{3}$ & 611.71 & 316892.5 & 00.0 & 00.0 \\
\hline
\end{tabular}

Table 4. Microbiological determinations at Faucets.

\begin{tabular}{|c|c|c|c|c|c|c|c|}
\hline \multirow[b]{2}{*}{ Charges } & \multicolumn{4}{|c|}{ Germs indicators of contamination } & \multicolumn{3}{|c|}{ Pathogens } \\
\hline & $\begin{array}{c}\text { G.R CFU } / 100 \mathrm{ml} \text { at } \\
20^{\circ} \mathrm{C}\end{array}$ & $\mathrm{TC}$ CFU/100 ml & $\mathrm{FC} \mathrm{CFU/100} \mathrm{ml}$ & Stre. D CFU/100 ml & $\begin{array}{c}\text { S. aureus } \\
\mathrm{CFU} / 100 \mathrm{ml}\end{array}$ & $\begin{array}{l}\text { Salmonella } \\
\mathrm{CFU} / 100 \mathrm{ml}\end{array}$ & S.A.S CFU/20 ml \\
\hline Maximum & 00 & 00 & 00 & 00 & 00 & 00 & 00 \\
\hline Minimum & 00 & 00 & 00 & 00 & 00 & 00 & 00 \\
\hline Average & 00.0 & 00.0 & 00.0 & 00.0 & 00.0 & 00.0 & 00.0 \\
\hline
\end{tabular}


present in the water. According to these standards, drinking water must be free of pathogens (bacteria, viruses) and parasitic organisms, due to the health risks associated with these micro-organisms. Indeed, water microbiological analyzes allow to assess the risk of pathogenic micro-organisms, which can be found in the waters destined to domestic use, and that could by consequent cause diseases, and also makes it possible to control the effectiveness disinfection treatments, MakhloufI \& Abdelouahid (2011).

The results obtained from this study carried out in certain randomly selected faucets, sources, fountain waters, in the Beni Mellal city and its agricultural surrounding environs, are generally proper for consumption, as the results obtained from isolation and enumeration of bacteria reflecting hygienic degree such as Total Coliforms, Fecal Coliforms, Streptococcus D and germs that threat consumer's health such as $S$. aureus, Anaerobic Sulphite-reducing Bacteria and Salmonella, were negative (total absence) especially for faucets (treated water), sources (natural water) and fountains (no-treated water). However, water analysis of wells shows a high load amount of bacteria reflecting hygienic degree and also an important charge has been found for $S$. aureus. Conversely, wells waters were negative for Salmonella and Anaerobic Sulphite-reducing Bacteria enumeration. According to Al Otaibi (2009), the presence of coliforms in drinking water is enough grounds for assuming that a potential health hazard existed (possible presence of pathogens). Water quality requires guidelines and standards setting permissible limits for each parameter, UNICEF \& WHO (2008), and Kravitz, Nyaphisi, Mandel, et al. (1999). In addition, the guidelines conferred by WHO on water are generally adopted as the international reference point for standards by those countries not having their own standards. The WHO, data on faecal coliform bacteria group them into the following risk categories: $0 \mathrm{CFU} / 100 \mathrm{ml}$ (conformity); 1 - $10 \mathrm{CFU} / 100 \mathrm{ml}$ (low risk); 10 - $100 \mathrm{CFU} / 100 \mathrm{ml}$ (intermediate risk); $100-1000 \mathrm{CFU} / 100 \mathrm{ml}$ (high risk); and 41,000 CFU/100 $\mathrm{ml}$ (very high risk), WHO (1997). Concerning Moroccan and Canadian recommendations for the quality of drinking water, in Morocco as in Canada, the maximum acceptable concentration of total coliforms in drinking water has been established at "no detectable micro-organisms per $100 \mathrm{ml}$ volume", Norme Marocaine (1991). Taken at whole, these national and international standards; we can conclude that all the analyzed samples (faucets, fountains and sources waters) remains generally consumable at microbiological point of view. This is indicating that there is no recent contamination of the analysed water, by human or animal faeces in these analysed points. As a result, these findings indicate highly proper quality compared to previously reported data in developing countries. Thus, Gwimbi (2011) in drinking water in Manonyane community in Lesotho especially for sources water. From this study, Gwimbi (2011) showed that the number of total coliform and $E$. coli counts found in unprotected water sources suggest that poor source water protection leads to a poor sanitation conditions which are potential reasons for the high presence of microbiological contaminants. The big difference in the microbial counts from water samples of similar protection status 
might be indicative of widely varying hygiene behaviours in the households. In our study, the analysed water originated from wells (groundwater) remains generally improper for consumption in comparison with available national and international standards and to previous studies. The results obtained in this station show that almost of wells samples were contaminated at advancing levels by reflecting hygienic bacteria. These load amounts are principally reflected by high charges of faecal contamination indicator parameters (faecal coliforms, total coliforms and Streptococcus D) encountered in groundwater originated from wells, which is due in most cases to human activities in the well environment. According to Diop (2006), the absence of these bacteria in $100 \mathrm{ml}$ of filtered water is standardized by regulation. Faecal streptococci are also among the most commonly used as faecal contamination indicator group for drinking water. Faecal streptococci are much more resistant to disinfection including chlorine than most pathogenic organisms and coliforms. This explains their presence in drinking water and gives them a certain interest for the control of treatment efficiency, Diop (2006). Total coliforms are a group of bacteria that are frequently found in the environment, for example in soil or vegetation, as well as in the intestines of mammals, including humans. Total coliforms generally do not cause disease, but their presence indicates that a source of water can be contaminated by more harmful microorganisms. E. coli is the only member of the total coliform group found exclusively in the intestines of mammals, including humans. The presence of $E$. coli in water indicates recent faecal contamination, and may indicate the possible presence of disease-causing pathogens Ministère de l'Environnement (2004), and Ivey, deLoe, Kreutzwiser et al. (2006), such as bacteria, viruses and parasites. According to Ivey, deLoe, Kreutzwiser et al. (2006), the presence of $E$. coli in water suggests enteric pathogens and faecal pollution; this has been also reported to be the causative agent of haemorrhagic colitis, diarrhoea, urinary tract infection, and haemolytic uraemia syndrome in similar studies elsewhere according to Esrey, Feachen, \& Hughes (1985).

The interest of the detection of these coliforms makes it possible to detect a faecal contamination resulting for example from infiltrations of polluted water in the pipes. They are also good indicators of the effectiveness of water treatment. Regarding the search of revivable germs in the waters analyzed, our findings showed high loads for water mainly originated from sources, and fountains. However, there is a total absence of these germs in water wells originated from faucets (treated water).

Concerning pathogenic bacteria, the search of germs such as $S$. aureus, Salmonella and Anaerobic Sulphite-reducing Bacteria in the whole analyzed samples revealed a total absence in all almost faucets, sources and fountains waters while $S$. aureus was only detected, at treating levels, in well waters. In general, this contamination could occur during and after precipitation, bacteria and other dangerous micro-organisms can enter rivers, lakes and groundwater. A poorly constructed or poorly maintained well can increase the risk of contamination. As a result, these waters are considered unfit for consumption. In literature reviews, 
the harmful effect of wastewater on the quality of surface and groundwater and also on the quality of food stuffs and human health has been demonstrated by several studies, Kholtei, Bouzidi, Bonini et al. (2003), Montiel (2004), El Kettani \& Azzouzi (2006), Talouizte, Merzouki, El Ouali et al. (2007), and El Ouali, Zanibou, Bekhti et al. (2014). As well, urban wastewater contains also a lot of nutrients (macronutrients $\mathrm{N}, \mathrm{P}, \mathrm{K}, \mathrm{Ca}, \mathrm{Mg}$ and micronutrients $\mathrm{Fe}, \mathrm{Zn}, \mathrm{Cu}, \mathrm{Mn} . .$. ) which are extensively utilized by bacterial populations, El Ouali, Zanibou, Bekhti et al. (2014), and Thomas (1995).

Nowadays, several diseases that affect the planet's population are described to be partially associated to the inadequacy of the evacuation of domestic and industrial wastewater. These have become increasingly enormous in the face of industrial development, economic growth, population growth and the high density of urban areas. Without any treatment, these wastewaters present an increasing danger to human health and the natural environment because of their toxic chemical charges and pathogenic microorganisms (bacteria, viruses, parasites, etc.). They are therefore permanent and serious threats to both human and animal health, Talouizte, Merzouki, El Ouali et al. (2007), Ait melloul, Amahmid, Hassani et al. (2002), and Nimri, El Nasser, \& Batchoun (2004). Of note, several studies of the impact of liquid effluents, particularly in Morocco, on groundwater quality have led to the wastewater being discharged without treatment, Zakari, Fekhaoui, \& Bahou (1993), Lyakhloufi, ER-Rouane, Ouazzani et al. (1999), Chalbaoui (2000), Tazi, Fahde, \& El Younoussi (2001), Kholtei, Bouzidi, Bonini et al. (2003), El Guamri \& Belghyti (2006), El Mostafa, Bouzidi, Koulali et al. (2006), Aboulkacem (2007), and El Mostafa, El Kettani, Koulali et al. (2010). From this, it appears the necessity and the importance of treatment of these wastewaters avoiding their random evacuation in environment.

\section{Conclusion}

In general, the majority of the water originated from faucets, fountains and sources is proper for consumption in microbiological point of view. Moreover, the water originated from wells is improper for consumption, because these waters were grossly polluted with coliforms and streptococcus $\mathrm{D}$. Wells waters were also contaminated with pathogenic germs such as $S$. aureus. The effects were generally attributed to a set of factors such as wastewaters evacuation in environment; poor wells water protection, poor sanitation and low level of hygiene practices, and lack of monitoring and healthcare awareness. It appears, from the results obtained, that the potential risk of infection of water consumers especially (groundwater) calls for prompt intervention in order to alleviate the potential health impact of water-borne diseases in the community. From this, a proper sanitary survey and implementation of water and sanitation projects in the community is recommended.

\section{Conflicts of Interest}

The authors declare no conflicts of interest regarding the publication of this paper. 


\section{References}

Aboulkacem, A. (2007). Etude Comparative de la Qualité Bactériologique des Eaux des Oueds Boufekrane et Ouislane à la Traversée de la Ville de Meknès (Maroc). Revue de microbiologie industrielle, sanitaire, et environnementale, 1, 10-22.

AFNOR NF V 08-013 (1993). Microbiologie. Directives Générales pour la Recherche.

AFNOR NFT90-420 (1987). Examens Bactériologiques des Eaux Destinées à la Consommation Humaine.

AFNOR T90-414 (1985). Recherche et Dénombrement des Coliformes et des Coliformes Thermo Tolérant par Filtration sur Membrane.

Ait melloul, A., Amahmid, O., Hassani, L. et al. (2002). Health Effect of Human Wastes Use in Agriculture in El Azzouzia (the Wastewater Spreading Area of Marrakech City, Morocco). International Journal of Environmental Health Research, 12, 17-23. https://doi.org/10.1080/09603120120110022

Al Otaibi, E. L. (2009). Bacteriological Assessment of Urban Water Sources in Khamis.

Boyd, C. E. (2007). Water Quality: An Introduction. Berlin: Springer.

Chalbaoui, M. (2000). Vulnérabilité des Nappes Superficielles et Subaffleurantes du Sud-ouest Tunisien. Sécheresse, 11, 85-91.

ConsoGlobe (2019). Consommation d'Eau par Habitant dans le Monde-Planetoscope. Statistiques Mondiale en Temps Réel.

https://www.planetoscope.com/consommation-eau/239-consommation-d-eau-dans-lemonde.html

Cosgrove, W. J., \& Rijsberman, F. R. (2014). World Water Vision: Making Water Everybody's Business. Abingdon-on-Thames: Routledge. https://doi.org/10.4324/9781315071763

Diop, C. I. K. (2006). Etude de la Qualité Microbiologique des Eaux de Boisson Conditionnes en Sachet et Vendues sur la Voie Publique dans la Région de Dakar. Dakar: Université Cheikh Anta Diop de Dakar.

El Guamri, Y., \& Belghyti, D. (2006). Etude de la Qualité Physico-chimique des Eaux Usées Brutes de la Commune Urbaine de Saknia, Rejetées dans le Lac Fouarat (Kénitra, Maroc). Journal Africain des Sciences de l'Environnement, 1, 53-60.

El Kettani, S., \& Azzouzi, E. M. (2006). Prévalence des Helminthes au sein d'une Population Rurale Utilisant les Eaux Usées à des Fins Agricoles à Settat (Maroc). Environnement, Risques et santé, 2, 99-106.

El Mostafa, H., Bouzidi, A., Koulali, Y. et al. (2006). Effets des Rejets Liquides Domestiques et Industriels sur la Qualité des Eaux Souterraines au Nord de la Ville de Settat (Maroc). Bulletin de l'Institut Scientifique, Rabat, section Sciences de la Vie, 28, 61-71.

El Mostafa, H., El kettani, S., Koulali, Y. et al. (2010). Contamination Bactériologique des Eaux Souterraines par les Eaux Usées de la Ville de Settat, Maroc. Revue de microbiologie industrielle, sanitaire, et environnementale, 4, 11-21.

El Ouali, L. A., Zanibou, A., Bekhti, K. et al. (2014). Contrôle de la Qualité Microbiologique des Eaux Usées Domestiques et Industrielles de la Ville de Fès au Maroc (Microbiological Control Wastewater Domestic and Industrial City of Fes Morocco). Journal of Materials and Environmental Science, 5, 2325-2332.

Esrey, S. A., Feachen, R. G., \& Hughes, J. M. (1985). Interventions for the Control of Diarrhoeal Diseases among Young Children: Improving Water Supplies and Excreta Disposal Facilities. Bulletin of the World Health Organization, 63, 757-772.

Gwimbi, P. (2011). The Microbial Quality of Drinking Water in Manonyane Community: 
Maseru District (Lesotho). African Health Sciences, 11, 474-480.

Henri, L. (2002). Service de Bactériologie. Centre Hospitalier de Lille. Presse Therm Climat, 139, 9-13.

ISO 6222 (1999). Qualité de l'Eau: Dénombrement des Micro-organismes Revivifiables.

ISO 6461-1 (1993). Recherche et Dénombrement des Spores de Microorganismes Anaérobies Sulfito-réducteurs. Partie 1. Méthode par Enrichissement dans un Milieu Liquide.

Ivey, J. L., deLoe, R., Kreutzwiser, R. et al. (2006). An Institutional Perspective on Local Capacity for Source Water Protection. Geoforum, 37, 944-957. https://doi.org/10.1016/j.geoforum.2006.05.001

Norme Marocaine NM 03.7.001. (1991). Version 1991. https://www.yumpu.com/fr/document/view/31913203/royaume-du-maroc-ministere-d e-lequipement-et-des-transports/63

Kholtei, S., Bouzidi, A., Bonini, M. et al. (2003). Contamination des Eaux Souterraines de la Plaine de Berrechid dans la Région de la Chaouia, au Maroc, par des Métaux Lourds Présents dans les Eaux Usées: Effet de la Pluviométrie. Vecteur Environnement, 5, 68-81.

Kravitz, D. J., Nyaphisi, A., Mandel, R. et al. (1999). Quantitative Bacterial Examination of Domestic Water Supplies in the Lesotho Highlands: Water Quality, Sanitation and Village Health. Bulletin of the World Health Organization, 77, 829-836.

LeRoy, P. (1995). Troubled Waters: Population and Water Scarcity. Colorado Journal of International Environmental Law and Policy, 6, 299.

Lyakhloufi, S., ER-Rouane, S., Ouazzani, N. et al. (1999). Vulnérabilité et Risque de Pollution de la Nappe du Haouz de Marrakech (Maroc). Hydrogéologie, 3, 43-52.

MakhloufI, A., \& Abdelouahid, D. J. (2011). Etude de la Qualite Physicochimique et Microbiologique de l'Eau Potable dans la Ville de Bechar. Sud Ouest Algerie. In 1er Séminaire International sur la Ressource en Eau au Sahara: Evaluation, Economie et Protection (pp. 355-364). Ouargla.

Ministère de l'Environnement (2004). Etude sur la Qualité de l'Eau Potable dans Sept Bassins Versants en Surplus de Fumier et Impact Potentiel sur la Santé. Quebec.

Montiel, A. (2004). Contrôle et Préservation de la Qualité Microbiologique des Eaux: Traitements de Désinfection. Revue française des laboratoires, 364, 51-53. https://doi.org/10.1016/S0338-9898(04)80332-9

NF ISO 19458 (2006). Qualité de l'Eau-échantillonnage pour Analyse Microbiologique.

NF ISO 5667-3 (2004). Qualité de l'Eau-échantillonnage-Partie 3: Lignes Directrices pour la Conservation et la Manipulation Echantillon d'Eau.

Nimri, L. F., El Nasser, Z., \& Batchoun, R. (2004). Polymicrobial Infections in Children with Diarrhoea in a Rural Area of Jordan. FEMS Immunology and Medical Microbiology, 42, 255-259. https://doi.org/10.1016/j.femsim.2004.05.014

Organization Mondiale de la Santé (OMS) (2017). Directives de qualité pour l'eau de boisson. Quatrième édition, intégrant le premier additif (p. 564).

Planete (2018). Quelle Est la Consommation d'Eau par Habitant en France? https://www.futura-sciences.com/planete/questions-reponses/eau-consommation-eauhabitant-france-908

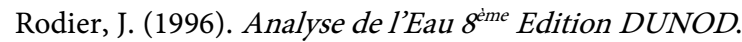

Talouizte, H., Merzouki, M., El Ouali, L. A. et al. (2007). Evolution de la Charge Microbienne de la Laitue Irriguée avec les Eaux Usées Urbaines de la Ville de Fès au 
Maroc. Tribune de l'eau, No. 642, 51-55.

Tazi, O., Fahde, A., \& el Younoussi, S. (2001). Impact de la Pollution sur l’Unique Réseau Hydrographique de Casablanca-Maroc. Sécheresse, 12, 129-134.

Thomas, O. (1995). Analyse Microbiologique dans «Métrologie des Eaux Résiduaires» (pp. 125-139). Ed cebedoc.

UNICEF \& WHO (2008). Progress on Drinking Water and Sanitation: Special Focus on Sanitation. New York: WHO/UNICEF Joint Monitoring Programme for Water Supply and Sanitation. http://www.who.int/iris/handle/10665/43931

United Nations (UN) (2015). Department of Economic and Social, Population Division World Population Prospects: The 2015 Revision: Key Findings and Advance Tables. New York.

WHO \& UNICEF (2006). Meeting the MDG Drinking Water and Sanitation Target: The Urban and Rural Challenge of the Decade. http://www.who.int/water_sanitation_health/monitoring/jmpfinal.pdf

WHO (1997). Guidelines for Drinking Water Quality. Surveillance and Control of Community Supplies. Geneva.

WHO (2003). World Health Report 2003: Shaping Our Future. World Health Organisation. http://www.who.int/whr/en

Zakari, H., Fekhaoui, M., \& Bahou, J. (1993). Etude de la Contamination Bactériologique de l'Oeud de Sebou Soumis aux Rejets de la Ville de Fès. Bulletin de l'Institut Scientifique (Rabat), No. 17, 47-55. 